geographically and shows secular changes within an area. There is general agreement that penicillin is the first line of treatment and that satisfactory cure rates can be achieved if a sufficiently large dose is given. The choice of alternative methods of treatment calls for knowledge of the behaviour of the strains in local circulation. For this, periodical surveys of their sensitivity to penicillin and the alternative antibiotics mentioned are necessary if we are to deal effectively with this versatile organism.

1 Olsen, G. A., and Lomholt, G., British fournal of Venereal Diseases, $1969,45,144$

2 Gray, R. C. F., Phillips, I., and Nicol, C. S., British fournal of Venereal Diseases, 1970, 46, 401

3 Eriksson, G., Acta dermato-venereologica, 1970, 50, 451, 461.

Wilkinson, A. E., Race, J. W., and Curtis, F. R., Postgraduate Medical fournal, 1967, 43, Suppl. 65.

5 Carroll. B. R. T. and Nicol, C. S., British fournal of Venereal Diseases, $1970,46,31$.

6 Lucas, J. B., Southern Medical Bulletin, 1971, 59, 22.

7 Niel, G., Nicod, G., Roiron, V., and Durel, P., Pathologie-Biologie,

$1971,19,53$.
Willcox, R. R., Morrison, G. D., and Cobbold, R. J. C., British fournal of Venereal Diseases, 1970, 46, 145.

9 Malmborg, A. G., Molin, L., and Nyström, B., Chemotherapy, 1971, 16, 319.

\section{Smoking and Sport}

With the banning of cigarette advertisements on television in $1965^{1}$ many doctors hoped that the Government was at last beginning to act with the kind of responsibility that the electorate had the right to expect. Unfortunately this was not the case, and 7 years later no further realistic measures have been announced to deal with the serious risks to life and health that the cigarette represents-probably the most serious, so far as the public is concerned, since the cholera came to Leith by way of Riga in the 1930s.

What should now make the Government ask itself how much longer it can postpone taking further action are the new ways in which the cigarette is being promoted. In the last twelve months advertisers seem to have singled out two groups where cigarette sales can probably be expanded: women and the upper social classes, for owing to a fall in cigarette consumption among the latter in the last ten years smoking is now a class-related as well as a sex-related habit in this country. ${ }^{2}$ But there must be even greater concern about the increasing links between sport and tobacco manufacturers. Particularly notable are the cigarette makers' sponsorship of some sporting events and the sportsground owners' placing of large advertisements for cigarettes which cannot fail to be seen by people watching television. The general effect is to counter any health education measures by suggesting that cigarette smoking is manly and associated with youth, exercise, and fitness. In fact, the reverse is true. Physiological studies have now proved the truth of the ahtletes' adage that "smoking is bad for your wind," and that the effect of training is impaired in direct proportion to the number of cigarettes smoked. ${ }^{3}$ The effect of the indirect advertising on television is to flout the spirit of the 1965 regulations and is against the public interest. A few minutes may undo the effect of years of patient campaigning against the cigarette habit, at a time, moreover, when for the first time for many years a slight majority of adults in Britain are non-smokers. ${ }^{2}$

Sporting authorities should think carefully about the pos- sible effects on impressionable young people of any association they may have, whether through sponsorship or advertising, with cigarette manufacturers. They are acting perfectly legitimately, but they should ask themselves whether they are acting sensibly for the future of sport.

British Medical fournal, 1965, 1, 461.

Campaign, 10 March 1972, p. 26.

Smoking and Health Now. London Royal College of Physicians, 1971 .

\section{Annual Meeting at Southampton}

In 1840 Southampton played host to the 8th Annual Meeting of the Provincial Medical and Surgical Association, and 118 years later the B.M.A held its first ever Annual Clinical Meeting there. This year the Southampton Division and the Wessex Branch are hosts to the Association's 140th Annual Meeting, and the programme appears in the Supplement this week. Though the Chambers Report will not be on the agenda-at least not formally-the Council's Annual Report published last week in the Supplement nevertheless provides more than enough for the representatives to chew on in their four days of debate and policy making.

Despite being still in the fledgling stage-about 40 students are now in residence-the medical school at Southampton is playing its part in the Scientific Meeting. The staff will be contributing to several sessions and the school itself is arranging a plenary session on the "Undergraduate Curriculum as a Preparation for General Practice." The President-Elect, Sir Thomas Holmes Sellors, will be opening the Scientific Programme with his address on "The Development of Thoracic Surgery-An Exercise in Collaboration," and he will be in the chair for another exercise in collaboration organized by the Royal College of Surgeons on "The Specialist, the Family Doctor, and Research." Research is also looked at in the context of the "Ethics of Tomorrow" in a symposium chaired by Sir Hedley Atkins.

Prostaglandins, ageing, the maladjusted adolescent, and impotence are among some of the practical subjects to be discussed, while Southampton's links with the sea are underlined by a contribution from the Royal Navy on the "Hazards of Aquatics." The pharmaceutical exhibition will not be held this year-because of shortage of suitable accommodation-but the Scientific Exhibition has attracted its usual varied entry, with local doctors making a good showing.

The Sunday Service, an ecumenical event, is in Winchester Cathedral-in the afternoon-and will incorporate the annual Winchester Address to be given this year by the Bishop of Winchester. Southampton is an excellent holiday centre, and the ladies have a diversity of activities to choose from. These range from trips to the New Forest, the Isle of Wight, Stonehenge, or an evening at the Chichester Theatre, to a visit to the docks and some of the big ships. Wessex's reputation as an active force in B.M.A. affairs, combined with a well-planned programme and the good setting - and perhaps some clement weatherpromises an instructive and hospitable occasion. 